\title{
A Potential Cholinergic Mechanism of Procaine's Limbic Activation
}

\author{
Brenda E Benson*, ${ }^{*, 3}$, Richard E Carson ${ }^{2}$, Dale $O$ Kiesewetter ${ }^{2}$, Peter Herscovitch², William C Eckelman², \\ Robert M Post' and Terence A Ketter ${ }^{1,4}$ \\ 'Biological Psychiatry Branch, NIMH, NIH, Bethesda, MD, USA; ${ }^{2}$ Positron Emission Tomography Department, NIH, Bethesda, MD, USA; \\ ${ }^{3}$ Neuroscience and Cognitive Science Program, University of Maryland, College Park, MD, USA; ${ }^{4}$ Department of Psychiatry and Behavioral \\ Sciences, Stanford University, Stanford, CA, USA
}

\begin{abstract}
The local anesthetic procaine, when administered to humans intravenously (i.v.), yields brief intense emotional and sensory experiences, and concomitant increases in anterior paralimbic cerebral blood flow, as measured by positron emission tomography (PET). Procaine's high muscarinic affinity, together with the distribution of muscarinic receptors that overlaps with brain regions activated by procaine, suggests a muscarinic contribution to procaine's emotional and sensory effects. This study evaluates the effects of procaine on cerebral muscarinic cholinergic receptors in the anesthetized rhesus monkey. Whole brain and regional muscarinic receptor binding was measured before and after procaine administration on the same day in three anesthetized rhesus monkeys with PET and the radiotracer 3-(3-(3[ $\left.{ }^{18} \mathrm{~F}\right]$ fluoropropylthio)-1,2,5-thiadiazol-4-yl)-1,2,5,6-tetrahydro-I-methylpyridine ([ $\left.\left.{ }^{18} \mathrm{~F}\right] \mathrm{FP}-\mathrm{TZTP}\right)$, a cholinergic ligand that has preferential binding to muscarinic $\left(M_{2}\right)$ receptors. On separate days each animal received six different doses of i.v. procaine in a randomized fashion. Procaine blocked up to $\sim 90 \%$ of $\left[{ }^{18} \mathrm{~F}\right.$ FP-TZTP specific binding globally in a dose-related manner. There were no regional differences in procaine's inhibitory concentration for $50 \%$ blockade $\left(\mathrm{IC}_{50}\right)$ for $\left[{ }^{18} \mathrm{~F}\right.$ FP-TZTP. Tracer delivery, which was highly correlated to cerebral blood flow in previous monkey studies, was significantly increased at all doses of procaine with the greatest increases occurring near procaine's $I_{50}$ for average cortex. Furthermore, anterior limbic regions showed greater increases in tracer delivery than nonlimbic regions. Procaine has high affinity to muscarinic $M_{2}$ receptors in vivo in the rhesus monkey. This, as well as a preferential increase of tracer delivery to paralimbic regions, suggests that action at these receptors could contribute to i.v. procaine's emotional and sensory effects in man. These findings are consistent with other evidence of cholinergic modulation of mood and emotion. Neuropsychopharmacology (2004) 29, 1239-1250, advance online publication, 3 March 2004; doi: I 0. I 038/sj.npp. 1300404
\end{abstract}

Keywords: muscarinic receptors; procaine; FP-TZTP; limbic system; brain imaging, monkey

\section{INTRODUCTION}

The local anesthetic procaine has unique neuropsychopharmacological properties that make it useful as a discrete probe of the limbic system and associated studies of emotion. In this regard, it has been used as an affective challenge in healthy volunteers (Ketter et al, 1996; ServanSchreiber et al, 1998), and patients with mood disorders (Ketter et al, 1993) and panic disorder (George et al, 1993),

Presented in part at the Society for the Biological Psychiatry Annual Meeting, Toronto, Canada, 1998. Biological Psychiatry 43: 27S-28S.

* Correspondence: BE Benson, Department of Health and Human Services, National Institutes of Health, National Institute of Mental Health Biological Psychiatry Branch, Bldg 10 Rm 3S239, 10 Center Drive, Bethesda, MD 20892-1272, USA, Tel: + I 301496 6825, Fax: + I 301402 0052, E-mail: bbenson@mail.nih.gov

Received 19 June 2003; revised 22 December 2003; accepted 29 December 2003

Online publication: 5 January 2004 at http://www.acnp.org/citations/ Npp0 I050403270/default.pdf as well as in individuals abusing alcohol (George et al, 1990) and cocaine (Adinoff et al, 2001).

Procaine $(1.84 \mathrm{mg} / \mathrm{kg})$, when administered intravenously (i.v.) in healthy volunteers (Kellner et al, 1987), results in brief intense emotional (ranging from euphoria to dysphoria) and sensory experiences (visual, auditory, and olfactory illusions/hallucinations) in association with increased relative anterior paralimbic cerebral blood flow (CBF) as measured with $\left[{ }^{15} \mathrm{O}\right]$ water positron emission tomography (PET) (Ketter et al, 1996). In healthy individuals, procaine also induces the following: hormonal changes such as increased adrenocorticotropic hormone (ACTH), cortisol, and prolactin (Kling et al, 1994); and increased temporal lobe fast activity electroencephalogram (EEG) (Parekh et al, 1995). Furthermore, the right amygdala blood flow correlated with the degree of affective arousal, while the left amygdala CBF correlated positively with the degree of dysphoria and negatively with the degree of euphoria (Ketter et al, 1996). The experiences described by the subjects in these procaine studies are reminiscent of those reported after direct stimulation of limbic cortex during 
epilepsy surgery (Gloor et al, 1982; Halgren et al, 1978; Penfield and Jasper, 1954). The emotional and endocrine changes also resemble the effects of acute challenge with the anticholinesterase drug physostigmine (Janowsky et al, 1986).

The neurochemical mechanisms of procaine's emotional, sensory, and endocrine effects could provide valuable insights into the neurobiology of normal and pathological emotion regulation, but have not been clearly elucidated. Procaine is classically associated with the blockade of voltage-gated sodium channels producing the local anesthetic effect for which it was designed and synthesized by Einhorn in 1905. Procaine produces 50\% inhibition of the action potential at $1.1 \mathrm{mM}$ in frog and rat sciatic nerve (Butterworth and Strichartz, 1990), by binding in the channel pore and altering the gating mechanism to increase the probability of the inactive state, thereby reducing the likelihood of an action potential (Butterworth and Strichartz, 1990). Site-directed mutations in rat brain sodium channels show reduced use-dependent blockade, confirming this hypothesis (Scholz, 2002). Procaine is also hypothesized to have direct effects on the lipid bilayer and hence indirectly influence components in the neuronal membrane (De Jong, 1994).

Procaine also interacts with many neurochemical systems, but is most potent at the muscarinic cholinergic receptor. Procaine competitively displaces quinuclidinyl benzilate (QNB), a nonspecific muscarinic antagonist at putative $M_{2}$ receptors in the guinea-pig ileum with a delivery rate constant $\left(K_{\mathrm{i}}\right)$ of $4 \mu \mathrm{M}$ (Hisayama et al, 1989) and inhibits QNB binding $\left(K_{\mathrm{i}}=4 \mu \mathrm{M}\right)$ in rat hippocampal membranes known to have $\mathrm{M}_{1}$ and $\mathrm{M}_{2}$ receptors (Sharkey et al, 1988). In contrast, the affinity of procaine for $\mathrm{M}_{3}$ receptor was $5 \mathrm{mM}$ in the guinea-pig mesenteric artery (Itoh et al, 1981). Procaine inhibits methylcarbachol or dimethylphenylpipereeinium (DMPP) binding presumably at nicotinic cholinergic receptors on rat brain membranes at higher concentrations $\left(K_{\mathrm{i}}=50-100 \mu \mathrm{M}\right.$ depending on the agonist used) than observed in the muscarinic system (Saraswati et al, 1992). Sigma receptors are the only other sites at which procaine binds in the low micromolar range (3.6 $\mu \mathrm{M}$; Sharkey et al, 1988).

The affinity of procaine for other systems include transporters (dopamine (DA): $104 \mathrm{mM}$, norepinephrine (NE): $217 \mathrm{mM}$, and serotonin (5HT): $276 \mathrm{mM}$ ) and receptors (serotonin (0.1-10 mM, depending on subtype), neuropeptide $\mathrm{Y}(5 \mathrm{mM})$, angiotensin $(5 \mathrm{mM})$, endothelin $(5 \mathrm{mM})$, adrenergic $\left(a_{2}: 5 \mathrm{mM}, b_{1}: 100 \mathrm{mM}\right)$, glycine $(1 \mathrm{mM})$, glutamate $(1 \mathrm{mM})$, and gamma-aminobutyric acid (GABA) (1.5-5.4 mM per subunit); Aoshima et al, 1992; Cunningham and Lakoski, 1988; Fishlock and Parks, 1966; Itoh et al, 1981; Napier, 1992; Ritz et al, 1987; Sharkey et al, 1988; Sugimoto et al, 2000; Sato et al, 2000). It should be noted that for some ligands affinity constants were not determined, but stated doses had no biological effects, such as $\mathrm{D}_{1}$ and $D_{2}$ receptors (Napier, 1992). Thus, based on affinities, procaine would be expected to have primary actions on the muscarinic cholinergic and sigma receptor systems that could be important contributors to its clinical effects.

Cholinergic $M_{1}$ and $M_{2}$ receptors are present in core limbic areas, such as amygdala and hippocampus, as well as primary sensory regions. While $\mathrm{M}_{1}$ receptors have primarily a cortical distribution, $\mathrm{M}_{2}$ receptors have a more uniform distribution across the brain, cortically and subcortically (Mesulam, 1995; Mesulam et al, 1983; Flynn and Mash, 1993). Telencephalic cholinergic projections originating in the basal forebrain nuclei, such as the nucleus basalis, send efferents to most of the cortex, including the anterior cingulate, as well as to subcortical regions, the basolateral amygdala, and hippocampus (Mesulam, 1995; Mesulam et al, 1983). Of particular interest are the efferents of the basolateral amygdala that heavily innervate the anterior cingulate and nearby medial orbitfrontal cortex (Russchen et al, 1985). These anterior paralimbic regions with direct and indirect cholinergic connections are also the areas that exhibit the most robust activation by procaine in humans (Ketter et al, 1996). Thus, the distribution and the potential functional consequences of the cholinergic receptors in limbic pathways could allow cholinergic mechanisms to play an important role in emotion (Heimer, 2003).

Cholinergic drugs have been shown to influence limbic regions known to mediate mood, reward, and aggression. For example, neuronal activity in the dorsolateral prefrontal and orbitofrontal cortex, and the amygdala of monkeys has been shown to be altered by iontophoretic administration of cholinergic agents (Aou et al, 1983; Inoue et al, 1983; Lenard et al, 1989). Similar to GABA, procaine microinjection (6-20 mg) into rat nucleus basalis inhibits frontal cortical neuronal firing in response to conditioned stimuli (pairing with medial forebrain stimulation) (Rigdon and Pirch, 1984). Moreover, procaine selectively activates limbic structures electrophysiologically in rats (Munson et al, 1970; Racine et al, 1975, 1979; Wagman et al, 1967). Utilizing 2-deoxyglucose methodology, lidocaine, a closely related amide local anesthetic, selectively activated limbic structures in rats (Post et al, 1984). Local anesthetics, including cocaine, lidocaine and procaine, can produce kindled seizures and aggressive behavior in rodents (Post, 1981). Intra-amygdalar injection of cholinomimetics also induces kindled seizures (similar in appearance to those evoked by electrical amygdaloid kindling), which can be blocked by muscarinic antagonists (Cain, 1981). Furthermore, atropine, a muscarinic antagonist, inhibits and physostigmine weakly facilitates procaine-induced kindling in rats (Heynen et al, 1995).

In summary, cholinergic modulation could contribute significantly to procaine-induced emotional and sensory experiences. This is suggested by procaine's: (1) preferential affinity to $\mathrm{M}_{2}$ muscarinic cholinergic receptors that are localized in key limbic areas; (2) ability to selectively activate limbic structures associated with emotion regulation while producing concomitant clinical electrophysiological effects; and (3) similarities in action to muscarinic agonists. In this study, we specifically explore the potential role of the muscarinic system in procaine's effects by measuring muscarinic receptor binding in anesthetized rhesus monkeys with the PET radioligand $\left[{ }^{18} \mathrm{~F}\right] \mathrm{FP}-\mathrm{TZTP}$, 3-(3-(3[ $\left.{ }^{18} \mathrm{~F}\right]$ fluoropropylthio)-1,2,5-thiadiazol-4-yl)-1,2,5,6tetrahydro-1-methylpyridine (Kiesewetter et al, 1995) before and after procaine administration.

We hypothesized that the binding of $\left[{ }^{18} \mathrm{~F}\right] \mathrm{FP}-\mathrm{TZTP}$ would be reduced by procaine as a function of the dose administered. In addition, we hypothesized that the $K_{1}$ of the ligand, which correlates strongly with CBF (Carson et al, 1998), would have a pattern of specific limbic increases 
similar to those observed with $\mathrm{CBF}$ in human studies (Ketter et al, 1996), although this effect could be attenuated by anesthesia.

\section{METHODS}

\section{Subjects}

Four adult male rhesus monkeys (Macaca mulatta) weighing $11.7,8.8,8.0$, and $7.1 \mathrm{~kg}$ were studied with brain imaging techniques while receiving general anesthesia during the entire procedure. One animal was unable to complete the whole series of studies due to arterial port failure, and thus was not included in the analysis. All studies were performed under a protocol approved by the NIH Clinical Center Animal Care and Use Committee. The monkeys were routinely monitored by veterinary staff, housed according to American Association for Laboratory Animal Care (AALAC) standards in individual cages, allowed ample feed and were provided with psychological enrichment.

\section{Experimental Design}

Animals underwent PET with the radiopharmaceutical 3-(3(3[ $\left.{ }^{18} \mathrm{~F}\right]$ fluoropropyl)thio)-1,2,5-thiadiazol-4-yl)-1,2,5,6-tetrahydro-1-methylpyridine ([ $\left.\left.{ }^{18} \mathrm{~F}\right] \mathrm{FP}-\mathrm{TZTP}\right)$ while anesthetized with isoflurane. A total of 18 experiments, six with each animal, were conducted on separate days with each experiment separated by 20-180 days. On each study day, two dynamic PET scan sessions were collected, including an initial baseline scanning session with saline administration followed by a second with continuous infusion of procaine, at one of six doses, ranging from zero, 0.015625, 0.03125, $0.0625,0.125$, to $0.5 \mathrm{mg} / \mathrm{kg} / \mathrm{min}$ (active drug doses referred to as dose 1 to dose 5 , respectively). The order of procaine doses was randomized. These doses were chosen based on self-administration studies (Ford and Balster, 1976; Hammerbeck and Mitchell, 1978), while being safely under the seizure-inducing levels (Babb et al, 1979). These infusion rates were determined from procaine infusion rates from self-administration studies of $1 \mathrm{mg} / \mathrm{kg}$ per injection at an average rate of 24 injections per hour (Ford and Balster, 1976) and $4 \mathrm{mg} / \mathrm{kg}$ per injection at an average rate of nine injections per hour (Hammerbeck and Mitchell, 1978).

\section{Radiopharmaceutical}

$\left[{ }^{18} \mathrm{~F}\right] \mathrm{FP}-\mathrm{TZTP}$ (Kiesewetter et al, 1995, 1999) was developed as an extension of the structural class of $\mathrm{M}_{2}$ agonists made available by Nova Nordisk (Sauerberg et al, 1992). FP-TZTP exhibits modest selectivity for $M_{2}(2.2 \mathrm{nM})$ over $M_{1}(7 \mathrm{nM})$ receptors. Studies of crossreactivity with other neurotransmitter systems showed low affinity for all biogenic amine systems evaluated. FP-TZTP exhibited affinity for sigma-1 $(62 \mathrm{nM})$ and $5 \mathrm{HT}_{1}$ receptor $(2 \mu \mathrm{M})$ (Kiesewetter et al, 1995). The uniform uptake of $\left[{ }^{18} \mathrm{~F}\right] \mathrm{FP}-\mathrm{TZTP}$ across the brain resembles the distribution of $\mathrm{M}_{2}$ receptors, which is consistent with $\mathrm{M}_{2}$ selective binding. In rats, $\left[{ }^{18} \mathrm{~F}\right] \mathrm{FP}-\mathrm{TZTP}$ displays high uptake and high specific binding as determined by ex vivo autoradiography (Kiesewetter et al, 1999). In muscarinic knockout mice, the $\mathrm{M}_{2}$ knockout mouse is the only one that shows significantly reduced $\left[{ }^{18} \mathrm{~F}\right] \mathrm{FP}-\mathrm{TZTP}$ uptake in all brain tissues regions (Jagoda et al, 2003). Taken together, these data support $\left[{ }^{18} \mathrm{~F}\right] \mathrm{FP}-\mathrm{TZTP}$ preferential $\mathrm{M}_{2}$ binding in vivo. Tracer kinetic modeling for $\left[{ }^{18}\right.$ F]FP-TZTP has been developed by Carson et al (1998), so that PET data can be converted into parametric images of total binding ( $V$, volume of distribution) and radioligand delivery $\left(K_{1}\right)$. The binding of $\left[{ }^{18} \mathrm{~F}\right] \mathrm{FP}-\mathrm{TZTP}$ has been shown to be decreased by administration of physostigmine, and thus the binding was sensitive to endogenous acetylcholine (Carson et al, 1998). While other potential ligands, such as the nonselective muscarinic agonist CI-979 (Hartvig et al, 1997) or nonselective muscarinic antagonist $\left[{ }^{11} \mathrm{C}\right]$-scopolamine (Frey et al, 1992), and $\left[{ }^{11} \mathrm{C}\right] \mathrm{NMPB}$ (Zubieta et al, 2001) could contribute additional information pertaining to the profile of in vivo actions of potential agents on muscarinic receptors, $\left[{ }^{18} \mathrm{~F}\right] \mathrm{FP}-\mathrm{TZTP}$ was chosen over others due to its preferential binding to $\mathrm{M}_{2}$ receptors. Furthermore, the study design was conducive to using an ${ }^{18} \mathrm{~F}$ compound, particularly because a single synthesis generated the total radiotracer required for both phases of each study day.

\section{Procedure}

On the morning of the each procedure, the fasted animal was initially given $0.5 \mathrm{mg}$ ketamine and $5 \mathrm{cc}$ of $2.5 \%$ sodium pentathol intramuscularly to produce quasianesthesia for the placement of three i.v. lines, usually in both radial veins and a femoral vein, and intubation for eventual general anesthesia. The animal was transported to the PET suite and placed in the PET scanner and general anesthesia was induced with inhalation of $1-2 \%$ isoflurane using a StevensJohnson anesthesia machine.

The head was positioned in a stereotactic headholder for coronal image acquisition. An arterial line was attached to a permanent subcutaneous arterial port (Model 21-Y036, Sims Deltec, St Paul, MN) implanted in the femoral artery, a temperature probe was inserted into the rectum, and cardiopulmonary monitoring equipment leads were placed on the animal to monitor their cardiovascular, pulmonary, and thermoregulatory functions throughout the entire procedure (electrocardiogram (EKG), blood pressure, respiration rate, end-tidal $\mathrm{pCO}_{2}$, and temperature). Once cardiopulmonary measures were stable under anesthesia, the experimental procedures began.

After a transmission scan, two $\left[{ }^{18} \mathrm{~F}\right] \mathrm{FP}-\mathrm{TZTP}$ dynamic scan sessions were acquired. First, a series of dynamic scans were collected over $180 \mathrm{~min}$ with saline infusion. After the primary data collection period of $90 \mathrm{~min}$, procaine administration began and continued for the remainder of the experimental procedure. Sterile $10 \%$ procaine hydrochloride solution (Sanofi Winthrop Pharmaceuticals) was diluted with saline to desired concentrations on each experimental day and kept in the dark until experiments began, as procaine is light sensitive.

Procaine was administered i.v. in a continuous fashion with a Harvard pump. The syringe and i.v. lines were wrapped with aluminum foil to limit light exposure. The procaine dosing strategy involved a two-step infusion rate; a loading dose, which was double the target dose, was administered for $40 \mathrm{~min}$ and was followed by the target or maintenance dose for the remainder of the scanning session. At $40 \mathrm{~min}$ after beginning the target dose, the second set of 
dynamic scans was acquired over $90 \mathrm{~min}$, while the constant procaine infusion continued (mean interval between scans $185 \pm 2 \mathrm{~min}$ ). Upon completion of the experiment, the intravenous and arterial lines and monitoring equipment were removed, the animal was taken out of the PET scanner, returned to its home cage and allowed to recover from anesthesia.

$\left[{ }^{18} \mathrm{~F}\right] \mathrm{FP}-\mathrm{TZTP}$ was synthesized for each study day according to previously published methods (Kiesewetter et al, 1995, 1999). The product from a single radiosynthesis was split for two injections. The mean activity injected was $1.0 \pm 0.1 \mathrm{mCi}$ for the first injection (saline scan) and $3.5 \pm 1.6 \mathrm{mCi}$ for the second injection (procaine scan); mean $\left[{ }^{18} \mathrm{~F}\right]$ FP-TZTP mass was $0.4 \pm 0.2 \mathrm{nmol}$ for the first injection and $4.5 \pm 2.1 \mathrm{nmol}$ for the second injection; mean specific activity injected was $2700 \pm 1000 \mathrm{mCi} / \mu \mathrm{mol}$ for the first injection and $840 \pm 310 \mathrm{mCi} / \mu \mathrm{mol}$ for the second injection. More radioactivity was given for the second injection to attenuate the effect of the residual radioactivity from the first injection.

Arterial blood samples were drawn from the indwelling arterial port throughout the scanning procedure. A total of 29 blood samples $(0.5 \mathrm{ml})$ taken over the scanning period were centrifuged and $0.1 \mathrm{ml}$ plasma aliquots were counted in a calibrated gamma counter to generate time activity curves. Seven $1 \mathrm{ml}$ blood samples were obtained at $0,3,8,15,30,50$ and 90 min after injection for determination of the unmetabolized radiotracer fractions by thin layer chromatography (TLC) according to methods previously described (Carson et al, 1998).

Procaine levels were determined from three $2 \mathrm{ml}$ blood samples taken at 0,15 , and $45 \mathrm{~min}$ after the second injection of the radiotracer $(40,55$, and 85 min after maintenance dose was initiated); two drops of sodium arsenite per milliliter blood were added immediately to inhibit procaine metabolism by butyrylcholinesterases in blood. The samples were assayed for procaine levels by gas chromatography measuring the free procaine level in plasma (National Medical Services, Inc., Willow Grove, PA). Steady-state plasma concentrations were achieved through the loading/maintenance dose strategy, with procaine concentrations having a coefficient of variation of $9 \%$. No trends were observed over time among the three procaine samples. The mean plasma concentrations achieved are presented in Table 1.

\section{Imaging Data Collection and Analysis}

Image collection and analysis followed the methods of Carson et al (1998). Images were acquired with the General Electric Advance tomograph (DeGrado et al, 1994) in threedimensional mode, which collects 35 slices simultaneously with a 4.25 interslice distance and a $6 \mathrm{~mm}$ isotropic reconstructed resolution. Reconstructed scans were corrected for attenuation, scatter, random emissions, and deadtime, and calibrated in $\mathrm{nCi} / \mathrm{ml}$.

$\left[{ }^{18} \mathrm{~F}\right] \mathrm{FP}-\mathrm{TZTP}$ functional images of delivery rate from the plasma $\left(K_{1}(\mathrm{ml} \mathrm{plasma} / \mathrm{min} / \mathrm{ml}\right.$ tissue $\left.)\right)$ and equilibrium volume of distribution $(V(\mathrm{ml}$ plasma $/ \mathrm{ml}$ tissue $))$ or total binding were computed from the dynamic scans collected over the initial $45 \mathrm{~min}$, utilizing a kinetic model with an arterial input function that has been corrected for metabolites (Carson et al, 1998). Initially, the time delay between brain and blood sampling $(\Delta t)$ was determined by a onecompartment model fitting three parameters $\left(\Delta t, V, K_{1}\right)$. Functional images of $V$ and $K_{1}$ were created by first generating a pixel by pixel time activity curve adjusting for the global $\Delta t$, and then fitting to a two-parameter $\left(K_{1}\right.$ and $\left.V\right)$ model.

For the second injection, the data were adjusted for residual radioactivity and residual metabolites remaining from the first injection (baseline scanning). Images were corrected for residual activity and metabolites from the first injection with identical methodology as that of Carson et al (1998). Briefly, the model equation for the second injection was modified to include a nonzero initial radioactivity concentration $\left(C_{0}\right)$, which clears exponentially $\left(\exp \left(-k_{2} t\right)\right)$, where $k_{2}$ is the clearance rate constant of the second injection. For each pixel, $C_{0}$ was estimated by averaging the pixel value for the 30 min preceding the second injection (corrected for decay). This extrapolated background radioactivity amounted to less than $10 \%$ of total activity for the second injection. The magnitude of metabolites remaining from the first injection was estimated in a similar manner, and affected the early portion of the input function for the second injection.

Regions of interest (ROIs) were defined on coronal magnetic resonance imaging scans (MRIs) using the rhesus monkey atlas of Paxinos et al (2000). T1 weighted images

Table I The Effects of Procaine Administration on the Functional Response of the Cortex

\begin{tabular}{|c|c|c|c|c|c|c|c|}
\hline \multicolumn{2}{|c|}{ Procaine } & \multicolumn{3}{|c|}{$\left[{ }^{18} \mathrm{~F}\right]$ FP-TZTP Specific binding } & \multicolumn{3}{|c|}{ Tracer delivery } \\
\hline \multirow[b]{2}{*}{ Dose (mg/kg/min) } & \multirow[b]{2}{*}{ Plasma level $(\mu \mathrm{M})$} & \multicolumn{3}{|c|}{ BP $(\mathrm{ml} / \mathrm{ml})$} & \multicolumn{3}{|c|}{$K_{\mathrm{l}}(\mathrm{ml} / \mathrm{min} / \mathrm{ml})$} \\
\hline & & Baseline & Procaine & \% Decrease & Baseline & Procaine & $\%$ Increase \\
\hline 0.000 & 0.00 & $20.7 \pm 3.5$ & $22.4 \pm 3.9$ & -8.5 & $0.42 \pm 0.09$ & $0.45 \pm 0.13$ & 5.7 \\
\hline 0.016 & 0.65 & $20.9 \pm 6.2$ & $13.2 \pm 2.5$ & 35.1 & $0.40 \pm 0.17$ & $0.62 \pm 0.31$ & 51.7 \\
\hline 0.031 & 1.19 & $16.9 \pm 1.8$ & $10.3 \pm 0.8$ & 39.1 & $0.48 \pm 0.09$ & $0.62 \pm 0.13$ & 31.5 \\
\hline 0.063 & 2.92 & $16.3 \pm 4.5$ & $7.7 \pm 2.1$ & 52.5 & $0.38 \pm 0.11$ & $0.48 \pm 0.20$ & 22.6 \\
\hline 0.250 & 12.24 & $12.6 \pm 0.6$ & $2.7 \pm 0.8$ & 78.1 & $0.36 \pm 0.04$ & $0.43 \pm 0.10$ & 17.9 \\
\hline 0.500 & 21.37 & $20.1 \pm 9.7$ & $2.3 \pm 1.0$ & 88.6 & $0.36 \pm 0.05$ & $0.42 \pm 0.02$ & 19.5 \\
\hline
\end{tabular}

Procaine administration exhibited first-order kinetics in the plasma and blocked cerebral $\left.{ }^{18} \mathrm{~F}\right] \mathrm{FP}-\mathrm{TZTP}$ specific binding in a dose-related manner. The delivery rate of the ligand $\left(K_{1}\right)$ increased maximally at $0.016 \mathrm{mg} / \mathrm{kg} / \mathrm{min}$ procaine. Average cortical values for BP and $K_{1}$ are the mean across the three animals at baseline and with procaine administration; percent decreases in BP are measures of blockade (ie baseline minus procaine values) and $K_{\mathrm{I}}$ increases are procaine minus baseline values. 
were acquired on a GE Signa (1.5 Tesla), with a sequence 3D SPGR $(X=1 \mathrm{~mm}, Y=1 \mathrm{~mm}, Z=0.39 \mathrm{~mm})$, while sedated with ketamine and robinol on a separate day from the PET studies. The $V$ and $K_{1}$ images were coregistered to the structural MRIs using the Automated Image Registration (AIR) algorithm (Woods et al, 1998) that transformed and resliced the functional images into the coordinate system of the MRIs. Primary ROIs were anterior cingulate, amygdala, and basal forebrain structures ventral striatal and pallidal nuclei that were particularly activated in the human blood flow studies. Additional ROIs were defined in prefrontal, parietal, occipital, temporal cortices, thalamus, striatum, posterior cingulate, hippocampus, cerebellum, and brainstem. Primary sensory (V1, A1 and S1) and motor cortex (M1) were also measured, but not included into statistical inference testing as they were encompassed in some of the previously mentioned regions. The mean $V$ and $K_{1}$ levels were calculated from baseline and procaine scans for each ROI and a cortical average (prefrontal, anterior cingulate, posterior cingulate, parietal, occipital, and temporal cortices) was obtained.

The $V$ values measured at baseline $\left(V_{\text {base }}\right)$ and with procaine $\left(V_{\text {proc }}\right)$ administration were corrected for nonspecific binding by subtracting a uniform value of $7 \mathrm{ml} / \mathrm{ml}$ (rationale explained below) taken from preblocking studies with $\left[{ }^{18} \mathrm{~F}\right] \mathrm{FP}-\mathrm{TZTP}$ (Carson et al, 1998), yielding binding potential (BP) values for each scan (BP1 $=V_{\text {base }}-7$; $\left.\mathrm{BP} 2=V_{\text {proc }}-7\right)$. Percent blockade was calculated by

$$
\Delta \mathrm{BP}=100((\mathrm{BP} 1-\mathrm{BP} 2) / \mathrm{BP} 1)
$$

The relationship of average cortical blockade $(\Delta \mathrm{BP})$ to procaine dose was evaluated with repeated measure ANOVA with procaine dose as the one within factor, (SuperAnova, v1.11, Abacus Concepts, Berkeley, CA).

$\mathrm{IC}_{50}$ (inhibitory concentration for $50 \%$ blockade) values were calculated by two methods using Graphpad Prism software (v3.0a for Macintosh, Graphpad Software, Inc., San Diego, CA), and were compared for best fit. The first method determined $\mathrm{IC}_{50}$ from the percent blockade measures $(\triangle \mathrm{BP})$ with the two-parameter model equation:

$$
\Delta \mathrm{BP}=\Delta \mathrm{BP}_{\max }[L] /\left(\mathrm{IC}_{50}+[L]\right)
$$

where $\triangle B P_{\max }$ is the maximum percent blockade achievable with procaine. Ligand concentrations $[L]$ were based on mean procaine plasma levels acquired during each scanning period. The second fitting method used a sigmoidal doseresponse model fitting three parameters to the equation

$$
\Delta \mathrm{BP} 2=\mathrm{BP}_{\max }\left(1-\left(\Delta \mathrm{BP}_{\max } / 100\right)[L] /\left(\mathrm{IC}_{50}+[L]\right)\right)
$$

where $\mathrm{BP}_{\max }$ is the binding potential in the absence of procaine. These models differ in that the three-parameter model only used data from the second scan of each day and assumed a fixed value for $\mathrm{BP}_{\max }$ on all days for all animals. The two-parameter model used the baseline results (BP1) measured for each animal on each experimental day to directly calculate $\triangle \mathrm{BP}$. The three-parameter model also included the second-scan information on the zero-dose experimental day. Regional variations of $\mathrm{IC}_{50}$ values were assessed with repeated measure ANOVA with two within factors, region and procaine dose.

The statistical inferential methods for $K_{1}$ values were essentially identical to those described to assess BP measures. $K_{1}$ ROI values (without any corrections) measured at baseline $\left(K_{1 \text {-base }}\right)$ and with procaine $\left(K_{1 \text {-proc }}\right)$ administration were used to calculate percent change by

$$
\Delta \mathrm{K}_{1}=100\left(\left(K_{1-\text { proc }}-K_{1-\text { base }}\right) / K_{1-\text { base }}\right)
$$

The relationship of average cortical change of $K_{1}$ to procaine dose was evaluated with repeated measure ANOVA with one within factor, procaine dose. Regional variations of $K_{1}$ change were assessed with repeated measure ANOVA with two within factors, region and dose. When appropriate post hoc means comparisons were conducted, as in the case of testing the a priori hypothesis of selective anterior paralimbic, $K_{1}$ increases. Variability of peripheral measures was also examined with repeated measures ANOVA, with two within factors of dose and times.

Owing to the relative uniformity of muscarinic $\mathrm{M}_{2}$ receptor distribution across the brain, nonspecific binding measures were estimated in the following way. Since individual values were not available, a constant value for the nonspecific distribution of volume was used. Several constants were evaluated $(6,7,8$, and $8.7 \mathrm{ml} / \mathrm{ml}$ (the mean cortex value reported in Carson et al (1998) from preblocking studies)), but the $\mathrm{IC}_{50}$ estimates, regardless of constant value, remained essentially identical. For example, for the mean cortex $\mathrm{IC}_{50}$, a value of $1.34 \mu \mathrm{M}$ was obtained when using a constant value of $8.7 \mathrm{ml} / \mathrm{ml}$, as compared to $1.31 \mu \mathrm{M}$ obtained with $7 \mathrm{ml} / \mathrm{ml}$ for nonspecific distribution volume estimates. The constant value of $7 \mathrm{ml} / \mathrm{ml}$, approximately the mean value of the cerebellum from preblocking studies was chosen for the analyses, under the assumption that nonspecific binding is uniform across the brain. Note that the underestimation of nonspecific binding in this study would have the effect of underestimating the maximum percent blockade. Again using the cortex average as an example region, the $\triangle \mathrm{BPmax}$ using $8.7 \mathrm{ml} / \mathrm{ml}$ was $100.1 \%$, while $7 \mathrm{ml} / \mathrm{ml}$ produced a value of $88.4 \%$.

\section{RESULTS}

\section{Control Values}

On one day, each animal received saline administration during the second scanning period, in lieu of procaine, to establish test-retest reliability. Cortical $\left[{ }^{18} \mathrm{~F}\right] \mathrm{FP}-\mathrm{TZTP}$ BP did not differ significantly on retest (mean \pm SD saline1, $21.4 \pm 2.9 \mathrm{ml} / \mathrm{ml} ; \quad$ saline2, $23.1 \pm 3.4 ; \quad \mathrm{F}=1.48, \quad \mathrm{df}=1,2$, $p=\mathrm{ns})$. However, there was a slight tendency for regional $\left[{ }^{18} \mathrm{~F}\right] \mathrm{FP}-\mathrm{TZTP}$ BP changes from salinel to saline2, as indicated by a region $\times$ scan interaction $(\mathrm{F}=2.28$, $\mathrm{df}=12,24, p=0.04)$. Most regions increased slightly $1.0-$ $2.4 \mathrm{ml} / \mathrm{ml}$ (average change 5.9\%), but the thalamus, cerebellum, and the brainstem remained at the same level $(<0.8 \mathrm{ml} / \mathrm{ml}$ change). This slight trend of BP with time on anesthesia was also seen in the work of Carson et al (1998) and will tend to result in an underestimation of $\triangle B P$.

Cortical values for $\Delta K_{1}$ also showed a slight, but nonsignificant increase $(5.7 \%)$ from saline1 to saline2, a nonsignificant increase (mean $\pm S D$ saline1, $0.42 \pm 0.09$; saline2, $0.45 \pm 0.13 ; \mathrm{F}=0.53, \mathrm{df}=1,2, p=\mathrm{ns}$ ). Again there was significant regional variation $(\mathrm{F}=2.32, \mathrm{df}=12,24$, $p=0.04$ ) from saline1 to saline 2 . Most regions increased $0.02-0.133 \mathrm{ml} / \mathrm{min} / \mathrm{ml}$ (average change $11.2 \%$ ), but parietal 
and occipital cortex remained at the same level. These increases in $K_{1}$ are consistent with the work of Carson et al (1998) and most likely reflects time-related CBF increases associated with isoflurane administration (McPherson et al, 1994). These small increases in $K_{1}$ measures indicate that any procaine-induced flow increases may be slightly overestimated.

\section{Peripheral Measures}

There was no significant effect of procaine administration dose on heart rate (HR: $\mathrm{F}=1.21, \mathrm{df}=5,10, p=\mathrm{ns}$ ), systolic or diastolic blood pressure (SYS: $\mathrm{F}=0.90, \mathrm{df}=5,10, p=\mathrm{ns}$; DIA: $\mathrm{F}=1.04, \mathrm{df}=5,10, p=\mathrm{ns}$;), respiration rate ( $\mathrm{RR}$ : $\mathrm{F}=1.26, \mathrm{df}=5,10, \quad p=\mathrm{ns}), \quad$ or $\mathrm{pCO}_{2} \quad\left(\mathrm{pCO}_{2}: \mathrm{F}=1.46\right.$, $\mathrm{df}=5,10, p=\mathrm{ns})$. Although most measures significantly decreased with time (HR: $\mathrm{F}=11.27, \mathrm{df}=5,10, p=0.000$; SYS: $\mathrm{F}=6.47, \mathrm{df}=5,10, p=0.000 ;$ DIA: $\mathrm{F}=2.45, \mathrm{df}=5,10$, $p=0.030 ; \mathrm{RR}: \mathrm{F}=6.64, \mathrm{df}=5,10, p=0.000 ; \mathrm{pCO}_{2}: \mathrm{F}=8.37$, $\mathrm{df}=5,10, p=0.000)$, a drug $\times$ time interaction was only observed with $\mathrm{pCO}_{2}$ which was significantly increased on the highest dose $(0.500 \mathrm{mg} / \mathrm{kg} / \mathrm{min})$ after procaine administration and returned to baseline levels after cessation of the loading phase (HR: $\mathrm{F}=0.51, \mathrm{df}=5,10, p=\mathrm{ns}$; SYS: $\mathrm{F}=0.64, \mathrm{df}=5,10, p=\mathrm{ns} ; \mathrm{DIA}: \mathrm{F}=0.94, \mathrm{df}=5,10, p=\mathrm{ns}$; $\mathrm{RR}: \mathrm{F}=0.83, \mathrm{df}=5,10, p=\mathrm{ns} ; \mathrm{pCO}_{2}: \mathrm{F}=1.59, \mathrm{df}=5,10$, $p=0.016)$.

\section{Global Effects}

The $\mathrm{IC}_{50}$ values generated by the two fitting methods (twoparameter and three-parameter) differed by approximately a factor of 2. For example, the average cortical ROI $\mathrm{IC}_{50}$ values were $1.31 \mu \mathrm{M}$ and $0.75 \mu \mathrm{M}$ for the two- and threeparameter models, respectively. The percent coefficient of variation of $\mathrm{IC}_{50}$ from the fits was comparable at $\sim 30 \%$, thus model selection could not be performed based on goodness-of-fit. In subsequent results, the two-parameter results were chosen over the three-parameter results, because the former model directly accounted for day-today and animal-to-animal variability of baseline $\left[{ }^{18} \mathrm{~F}\right] \mathrm{FP}$ TZTP binding potential (Table 1).

Figure 1 depicts (top and middle panels) representative $\left[{ }^{18} \mathrm{~F}\right]$ FP-TZTP $V$ images with and without procaine coadministration in a single animal at the highest dose of 0.5 $\mathrm{mg} / \mathrm{kg} / \mathrm{min}$. Baseline and procaine global $\left[{ }^{18} \mathrm{~F}\right] \mathrm{FP}-\mathrm{TZTP}$ specific binding is reported in Table 1 . Procaine, in a doserelated manner, blocked average cortical $\left[{ }^{18} \mathrm{~F}\right] \mathrm{FP}-\mathrm{TZTP}$ total specific binding $(\mathrm{F}=51.45, \mathrm{df}=5,10, p=0.0001$; Figure 2$)$.

Procaine significantly increased average cortical $\left[{ }^{18} \mathrm{~F}\right] \mathrm{FP}$ TZTP $\Delta K_{1}$ values $(\mathrm{F}=6.23, \mathrm{df}=2,10, p=0.0071)$, however, not in a sigmoidal dose-related manner (Table 1). The peak change $(52 \%)$ in $K_{1}$ occurred at the low dose of $0.016 \mathrm{mg} / \mathrm{kg} / \mathrm{ml}$ (mean procaine plasma level $=0.65 \mathrm{mM}$; see Figure 1 bottom panel) and had successively smaller increases with each higher dose, although still increased by $20 \%$ at the highest dose of $0.5 \mathrm{mg} / \mathrm{kg} / \mathrm{min}$. The post hoc analysis of dose revealed all doses combined resulted in significantly higher $\Delta K_{1}$ values compared to the baseline study (baseline: $5.7 \pm 17.0 \%$; procaine: $28.6 \pm 17.3 ; \mathrm{F}=11.28$, $\mathrm{df}=1,10, p=0.007)$. This effect was attributable primarily to $0.016 \mathrm{mg} / \mathrm{kg} / \mathrm{min}$ dose with a $51.7 \%$ increase (dose $1 \mathrm{vs}$ baseline: $\mathrm{F}=27.16, \mathrm{df}=1,10, p=0.002)$ and also to the $0.031 \mathrm{mg} / \mathrm{kg} / \mathrm{min}$ dose with a $31.5 \%$ increase (dose $2 \mathrm{vs}$ baseline: $\mathrm{F}=23.54, \mathrm{df}=1,10, p=0.02$ ).

\section{Regional Effects}

The dose-response relationship of $\left[{ }^{18} \mathrm{~F}\right] \mathrm{FP}$-TZTP specific binding across the regions mirrored the global findings (Table 2). The regional IC $_{50}$ did not vary significantly across the areas measured and ranged from 1.00 to $2.25 \mu \mathrm{M}$ $(\mathrm{F}=0.88 ; \mathrm{df}=12,24 ; p=\mathrm{ns})$.

$\left[{ }^{18} \mathrm{~F}\right]$ FP-TZTP $\Delta K_{1}$ (Table 2) varied significantly across ROIs $(\mathrm{F}=5.58 ; \mathrm{df}=2,12 ; p=0.0001)$ and across procaine doses $(\mathrm{F}=5.61 ; \mathrm{df}=4,8 ; p=0.02)$; however, there was no interaction of region $\times$ dose $(\mathrm{F}=0.79 ; \mathrm{df}=60,120 ; p=\mathrm{ns})$. In the regional post hoc analysis, the $\Delta K_{1}$ of the anterior paralimbic areas (including the amygdala, anterior cingulate, basal forebrain nuclei, hippocampus, and prefrontal cortex, mean $\left.\Delta K_{1}=34.7 \%\right)$ was significantly increased compared with other regions (including posterior cingulate, occipital cortex, parietal cortex, cerebellum, and brainstem; mean $\left.\Delta K_{1}=21.0 \%, \mathrm{~F}=29.05, \mathrm{df}=1,24, p=0.0001\right)$.

\section{DISCUSSION}

In this PET study of anesthetized monkeys, procaine blocked the binding of a muscarinic ligand in a doserelated manner, globally and uniformly across the primate brain. The $\mathrm{IC}_{50}$ for the cortex was estimated to be $1.31 \mu \mathrm{M}$, which corresponds to plasma levels achieved between infusion doses 0.0312 and $0.0625 \mathrm{mg} / \mathrm{kg} / \mathrm{min}$ procaine. This is in the proximity of in vitro assessments of $\mathrm{M}_{2}$ muscarinic receptor $K_{\mathrm{d}}$ of $4 \mu \mathrm{M}$ as determined in rat hippocampal slices and guinea-pig ileum (Hisayama et al, 1989; Sharkey et al, 1988). Given the nearly $100 \%$ blockade achieved, these results support a direct interaction of procaine with the same muscarinic receptors to which $\left[{ }^{18} \mathrm{~F}\right] \mathrm{FP}$-TZTP is binding. Furthermore, the $V$ images of procaine administration at the maximal dose in this study were essentially identical to the $V$ images obtained during the preblocking experiments with $\left[{ }^{18} \mathrm{~F}\right] \mathrm{FP}-\mathrm{TZTP}$ studies (Carson et al, 1998).

Although procaine is known to selectively increase limbic electrophysiologic activity in animals and anterior paralimbic perfusion in humans (Heynen et al, 1995; Ketter et al, 1996; Munson et al, 1970; Parekh et al, 1995; Post, 1981; Post et al, 1984; Racine et al, 1975, 1979; Wagman et al, 1967), the lack of regional variation in $\mathrm{IC}_{50}$ values suggests that the competition of procaine with $\left[{ }^{18} \mathrm{~F}\right] \mathrm{FP}$-TZTP binding sites is similar across the brain. Furthermore, these data suggest that procaine's limbic selectivity is most likely not a result of limbic muscarinic receptors having enhanced regional sensitivity to procaine over that of other brain regions.

Nonetheless, the selective activation of paralimbic structures by procaine could still involve cholinergic mechanisms. Amygdalar neurons via muscarinic mediation have been associated with bursting phenomena (Yajeya et al, 1997), postsynaptically (Washburn and Moises, 1992) and presynaptically (Sugita et al, 1991). Bursting activity was further tied to a complement of presynaptic muscarinic receptors that were estimated to be comprised of $50 \% \mathrm{M}_{3}$, $30 \% \mathrm{M}_{2}$, and $20 \%$ or less $\mathrm{M}_{1}$, but most likely not due to the 

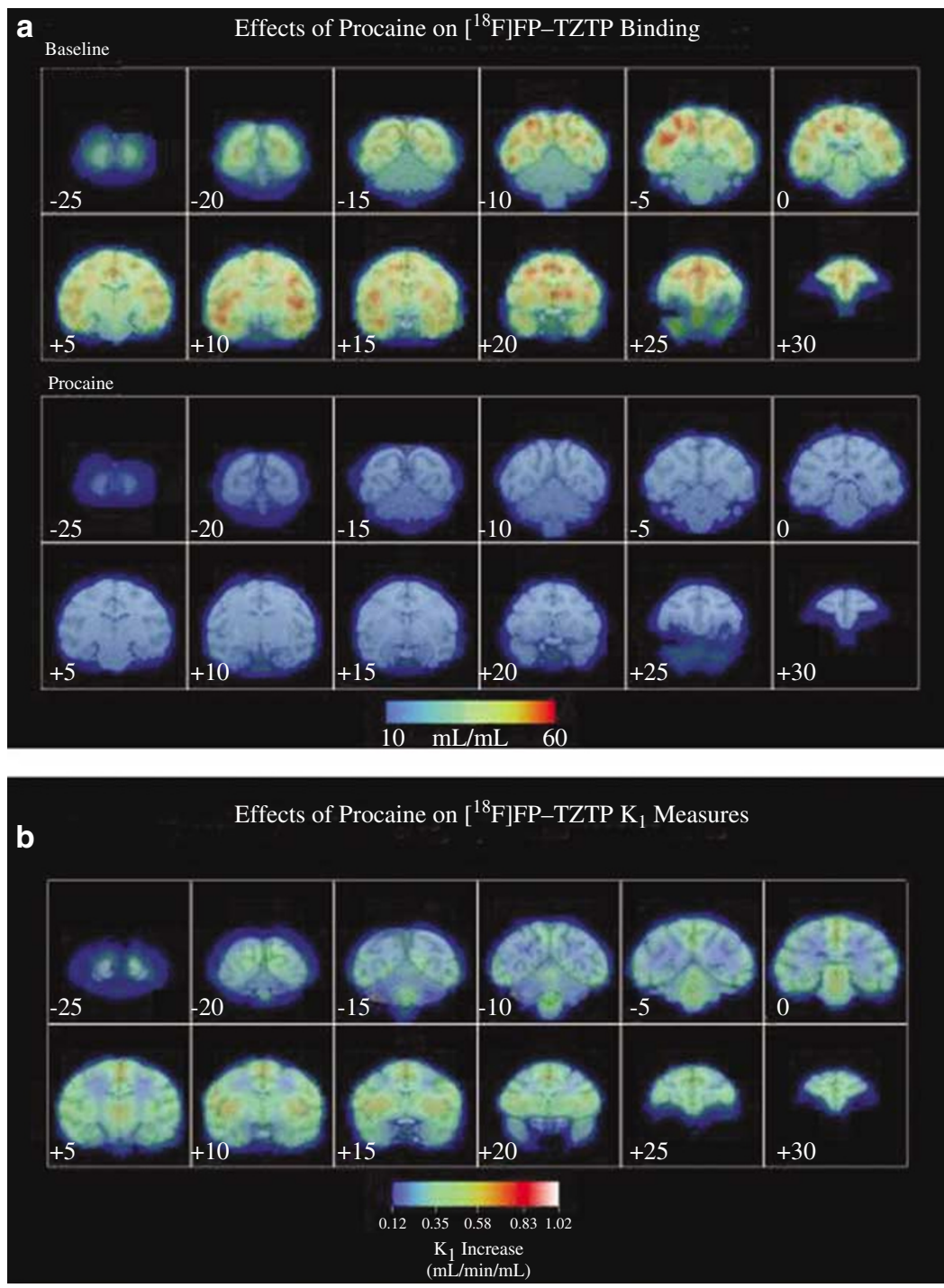

Figure I (a) Coronal slice presentation of volume of distribution images $(V$ from a single animal displaying the significant reduction in specific binding of $\left[{ }^{18} \mathrm{~F}\right.$ FP-TZTP by procaine. Global reduction in specific binding in this subject was $86.9 \%$. Upper panel-baseline binding is fairly uniform; lower panel_-procaine administration $(0.5 \mathrm{mg} / \mathrm{kg} / \mathrm{min})$ is essentially identical to preblocking studies with FP-TZTP (Carson et al, 1998). (b) Procaine increased $K_{1}$ measures the greatest in the anterior cingulate, striatum, and basal forebrain nuclei. Data represents a subtraction image in a single monkey $(0.016 \mathrm{mg} / \mathrm{kg} / \mathrm{min}$ procaine minus baseline). The PET images were registered to the animal's MR images; coordinates are mm rostral $(+)$ and caudal $(-)$ to ear canals.

well characterized M-current (Yajeya et al, 1997). Moreover, similar neuronal depolarization responses due to cholinergic mechanisms have been implicated in other paralimbic structures such as hippocampus, entorhinal, and piriform cortices and anterior cingulate (Benson et al, 1988; Colino and Halliwell, 1993; Hasselmo and Bower, 1992; Klink and Alonso, 1997; McCormick and Prince, 1986), as well as septum, basal forebrain, striatum, thalamus, and neocortical structures (Hasuo et al, 1988; Hsu et al, 1995; McCormick and Prince, 1987; Szerb et al, 1994). Thus, it is possible that procaine acting on $\mathrm{M}_{2}$ receptors could initiate bursting activity and enhance firing in limbic regions. These results suggest that the interaction of muscarinic receptors with the local neuronal environment could contribute to procaine's limbic effects.

It is likely that procaine is acting as an agonist since: cholinomimetics induce kindling similar to procaine
(Wasterlain et al, 1981); and physostigmine weakly facilitates procaine-induced kindling while atropine substantially slows this process (Heynen et al, 1995). Moreover, the clinical effects of physostigmine share similarities to procaine (Janowsky et al, 1986).

Conversely, however, antagonist activity is suggested by procaine competitively inhibiting acetylcholine-induced contraction (Ishii and Shimo, 1984) of guinea-pig cecum. Furthermore, procaine inhibits opening of cation channels on guinea-pig ileal smooth muscle cells thus affecting the acetylcholine-induced cationic currents; GTP $\gamma \mathrm{S}$ currents are inhibited in a similar manner (Chen et al, 1993). Lastly, procaine is known to have a biphasic effect on neuronal excitation with anticonvulsant activity at lower concentrations and proconvulsant activity at higher concentrations (De Jong, 1994; Foldes et al, 1960, 1965), which could reflect both agonist and antagonist cholinergic activity. 
Cerebral blood flow, as measured by $K_{1}$, significantly increased globally and regionally in the anterior paralimbic regions with all procaine doses, but the relationship of procaine dose and $K_{1}$ increase appears to be more complex than that observed with the binding data. The most robust increase was observed at the lowest dose of procaine and all

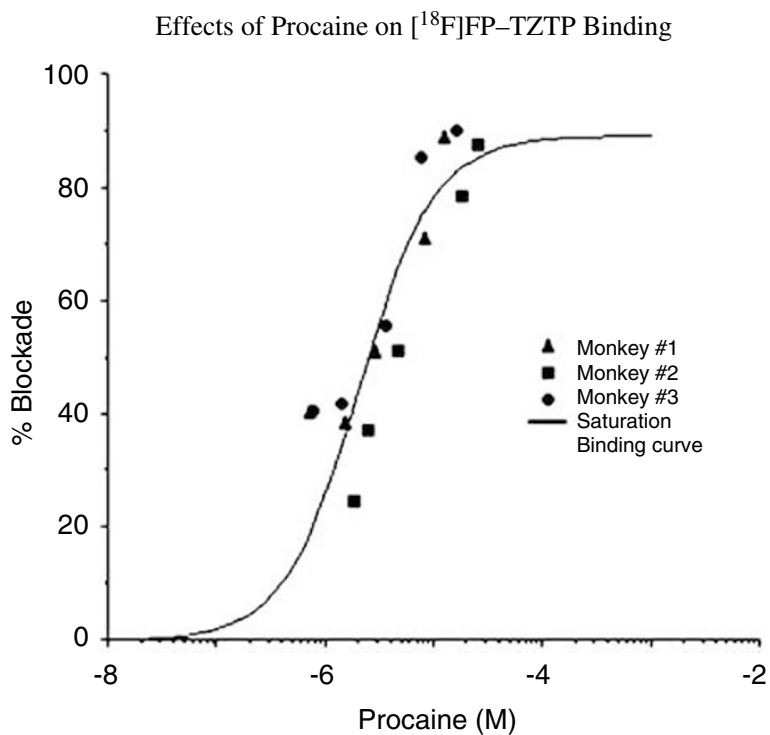

Figure 2 Procaine blocks cortical $\left[{ }^{18}\right.$ FFF-TZTP binding potential in a dose-related fashion that follows the saturation binding curve (solid line) with an $\mathrm{IC}_{50}$ of $\mid .4 \mu \mathrm{M}$ with an estimated accuracy of $\pm 0.4 \mathrm{I} \mu \mathrm{M}$. The maximum blockade was $87 \%$ and minimum was $23 \%$. subsequent higher doses resulted in less of an increase above baseline saline condition. The largest $K_{1}$ changes occurred at plasma levels near the $\mathrm{IC}_{50}$. This suggests that the $K_{1}$ effects associated with the lower doses could possibly be related to $M_{2}$ muscarinic blockade. However, the apparent reduction of the $K_{1}$ increase at the subsequently higher doses might be explained by procaine's effects on sigma or other receptors, or be a direct effect of the $\mathrm{M}_{2}$ receptors yielding a biphasic relationship of procaine dose on $K_{1}$. Allosteric modulation of the muscarinic receptor has been documented with cocaine (Flynn et al, 1992), and given the structural similarities between procaine and cocaine, such modulation could account for a smaller change in $K_{1}$ at higher doses. Another potential contributor to the complex $K_{1}$ changes observed in this study could be the reduced ability of the model to fit $K_{1}$ with higher receptor occupancy (Carson et al, 1998), resulting in an underestimation of $K_{1}$. This would yield lower flow changes than would be expected with a direct receptor blockade to flow relationship.

While it would be enticing to suggest that these $K_{1}$ changes reflect actual blood flow alterations, caution should be exercised. Despite the strong correlation of cerebral blood flow and $K_{1}(r=0.85$; Carson et al, 1998), the relationship of blood flow changes to procaine administration in this study can only be inferred. However, the regional pattern of $K_{1}$ increases in this study is similar to the blood flow increases observed in humans (Ketter et al, 1996). The $K_{1}$ data indicate that procaine binding to cholinergic $\mathrm{M}_{2}$ receptors may contribute to the overall activation of anterior paralimbic regions. This suggestion is

Table 2 Regional $\left[{ }^{18}\right.$ F FP-TZTP Parameter Values

Specific binding

\begin{tabular}{|c|c|c|c|c|c|}
\hline \multirow[b]{2}{*}{ Region } & & \\
\hline & Baseline BP (ml/ml) & ${ }^{\prime} C_{50}(\mu M)$ & $\Delta B P \max$ & Baseline $K_{\mathrm{l}}(\mathrm{ml} / \mathrm{min} / \mathrm{ml})$ & Maximal $K_{1}$ increase \\
\hline Striatum & $19.5 \pm 5.8$ & 1.48 & 88.9 & $0.48 \pm 0.12$ & 73.6 \\
\hline Anterior cingulate & $21.4 \pm 6.7$ & 1.00 & 85.4 & $0.43 \pm 0.10$ & 68.4 \\
\hline Hippocampus & $17.0 \pm 5 . \mid$ & 1.65 & 92.0 & $0.46 \pm 0.11$ & 57.5 \\
\hline Prefrontal & $17.0 \pm 5.1$ & 1.11 & 88.5 & $0.36 \pm 0.09$ & 54.8 \\
\hline Temporal & $17.4 \pm 5.4$ & 1.48 & 91.5 & $0.41 \pm 0.10$ & 54.2 \\
\hline Brainstem & $9.2 \pm 3.3$ & 2.25 & 97.7 & $0.41 \pm 0.12$ & 51.6 \\
\hline Posterior cingulate & $19.1 \pm 5.7$ & 1.36 & 85.2 & $0.40 \pm 0.09$ & 50.0 \\
\hline Cerebellum & $8.9 \pm 2.9$ & 2.12 & 100.4 & $0.62 \pm 0.17$ & 49.4 \\
\hline Primary auditory (AI) & $21.6 \pm 6.2$ & 1.37 & 87.6 & $0.48 \pm 0.11$ & 61.8 \\
\hline Primary somatosensory(SI) & $15.2 \pm 4.8$ & 1.45 & 91.4 & $0.33 \pm 0.07$ & 52.1 \\
\hline Primary motor (MI) & $16.7 \pm 5.5$ & 1.19 & 89.9 & $0.34 \pm 0.07$ & 66.6 \\
\hline
\end{tabular}

Cortical and regional $I C_{50}$ and $\Delta \mathrm{BP}_{\max }$ were estimated by saturation binding model for one site competition; their values remain fairly uniform across brain regions Procaine significantly increases $K_{1}$ values in all regions, especially in limbic areas; maximal $K_{1}$ increases listed here occurred with $0.0156 \mathrm{mg} / \mathrm{kg} / \mathrm{min}$ procaine. BP and $K_{1}$ values are mean $\pm \mathrm{SD}$.

Neuropsychopharmacology 
supported by preferential reductions in prefrontal cortex blood flow after scopolamine injection in humans in xenon133 PET studies (Honer et al, 1988), which are reversed by physostigmine (Prohovnik et al, 1997). Also, carbachol injection into the substantia inominata increases blood flow globally and in many limbic areas in rats (Barbelivien et al, 1999).

Procaine can have autonomic effects, such as increases or decreases in heart rate or blood pressure, when administered i.v. in humans (Foldes et al, 1965, 1960; Haasio et al, 1988; Scott, 1975). In this study, the minimal autonomic decreases observed are consistent with known effects related to time on anesthesia. It is notable that significant cerebral effects occurred while the peripheral effects were maximal.

There are several limitations to this study. Few animals were studied; despite this, the dose-response relationship of procaine blockade of $\left[{ }^{18} \mathrm{~F}\right] \mathrm{FP}-\mathrm{TZTP}$ was robust and consistent across each monkey (Figure 2). Further, the use of only rhesus monkeys suggest caution in extrapolation to man.

General anesthesia precluded the collection of behavioral measures during procaine administration restricting the scope of the study; the ability to relate the degree of blockade to behavioral measures would be a key element in determining a clearer role of the muscarinic system in the emotional and sensory effects of procaine. The general anesthesia (Durieux, 1996) may have confounded the $K_{1}$ changes observed, or interacted with procaine to alter the muscarinic activity (Brett et al, 1988; Dilger et al, 1992, 1993). Ketamine-muscarinic interactions (Durieux, 1995) may have also confounded the binding changes observed, but these effects would be present at baseline and with procaine. Anesthesia may have also limited the physiological changes potentially induced by procaine, either directly or indirectly.

Finally, different methods from those used in the human studies were necessary for the acquisition of the binding potential data, including the $\left[{ }^{18} \mathrm{~F}\right] \mathrm{FP}-\mathrm{TZTP}$ measurement after plasma procaine levels had leveled off, as well as the use of a constant infusion paradigm rather than a bolus administration. This may have resulted in assessing the procaine-flow relationship under different physiological conditions than in the human studies, limiting the ability to extrapolate from this study to the human studies.

With these caveats in mind, considerable evidence suggests a role for the cholinergic system in normal and pathological emotions. An enhanced ratio of cholinergic to adrenergic function has been hypothesized to play a role in mania and depression (Fritze, 1993; Janowsky et al, 1972b). Cholinergic challenge studies lend support to this theory. For example, physostigmine can reduce manic symptoms and exacerbate depressive symptoms in bipolar patients (Janowsky et al, 1972a). Furthermore, physostigmine administration results in relapse of depressive symptoms in bipolar patients successfully treated with lithium, while healthy controls do not develop depressed mood. These patients have concomitant hormonal disturbances and emotional arousal expressed as dysphoria (Janowsky et al, 1986).

Arecoline, a nonselective muscarinic agonist, has also induced dysphoria in mood disorder patients whether or not they were currently depressed; this was greater in individuals with a family history of depression compared to those without such history (Gillin et al, 1991; Nurnberger et al, 1989). Both arecoline (Sitaram et al, 1980) and donepezil, a cholinesterase inhibitor (Perlis et al, 2002) decrease REM latency in patients with major depression, but not in healthy controls.

In a $\left[{ }^{15} \mathrm{O}\right]$ blood flow study analyzing the functional associativity of cholinergic forebrain regions with and without procaine administration, some abnormalilties were found to normalize with procaine (Benson et al, unpublished data). At baseline, patients with mood disorders compared to healthy controls show significantly weaker positive relationships among the cholinergic forebrain regions, which became stronger and similar to controls with procaine. Thus, commonly reported alterations in prefrontal, anterior cingulate, temporal, striatal, and cerebellar brain regions in mood disorders (see reviews; Dougherty and Rauch, 1997; Ketter et al, 1997; Drevets, 1998) may have a cholinergic component to their dysregulation.

In conclusion, these data demonstrate that intravenous procaine administration in anesthetized monkeys was associated with a dose-related blockade of the $\mathrm{M}_{2}$ muscarinic ligand, $\left[{ }^{18} \mathrm{~F}\right] \mathrm{FP}-\mathrm{TZTP}$. This is the first demonstration of muscarinic cholinergic binding of procaine in primates, in vivo. In addition, cerebral blood flow $\left(K_{1}\right)$ was significantly increased in limbic regions of the brain. If significant receptor occupancy occurs at comparable plasma levels in humans, these data suggest a possible cholinergic contribution to the robust emotional and sensory effects of procaine and its ability to selectively activate amygdala and closely related anterior paralimbic structures. Thus, based on the binding and flow data presented here, procaine could prove to be another way of assessing muscarinic receptor tone in limbic areas in patients compared to healthy volunteers. Further studies to explore the relationship of muscarinic receptor activity with behavioral assessments, and use of agonist and antagonist ligands could delineate a clearer role of the cholinergic system in the effects of procaine on emotion.

\section{ACKNOWLEDGEMENTS}

We thank Wendy Turito and Wendy Linthicum for their assistance and expertise in animal PET studies.

\section{REFERENCES}

Adinoff B, Devous MD, Best SM, George MS, Alexander D, Payne K (2001). Limbic responsiveness to procaine in cocaine-addicted subjects. AM J Psychiatry 158: 390-398.

Aoshima H, Inoue Y, Ueda E, Kitagawa M, Nishino T (1992). Minimal model analyzing response of glycine receptors expressed in Xenopus oocyte: inhibition by a lipid hydroperoxide. J Biochem (Tokyo) 111: 523-528.

Aou S, Oomura Y, Nishino H (1983). Influence of acetylcholine on neuronal activity in monkey orbitofrontal cortex during bar press feeding task. Brain Res 275: 178-182.

Babb T, Perryman K, Lieb J, Finch D, Crandall P (1979). Procaineinduced seizures in epileptic monkeys with bilateral hippocampal foci. Electroencephalogr Clin Neurophysiol 47: 725-737.

Barbelivien A, Bertrand N, Besret L, Beley A, MacKenzie ET, Dauphin F (1999). Neurochemical stimulation of the rat substantia inominata increases cerebral blood flow (but not glucose use) through the parallel activation of cholinergic and non-cholinergic pathways. Brain Res 840: 115-124. 
Benson D, Blitzer R, Landau E (1988). An analysis of the depolarization produced in guinea-pig hippocampus by cholinergic receptor stimulation. J Physiology 404: 479-496.

Brett R, Dilger J, Yland K (1988). Isoflurane causes 'flickering' of the acetylcholine receptor channel: observations using the patch clamp. Anesthesiology 69: 161-170.

Butterworth J, Strichartz G (1990). Molecular mechanisms of local anesthesia: a review. Anesthesiology 72: 711-734.

Cain D (1981). Kindling: recent studies and new directions. In Wada J (ed). Kindling 2, Vol 2. Raven Press: New York. pp 49-66.

Carson RE, Kiesewetter DO, Jagoda E, Der MG, Herscovitch P, Eckelman WC (1998). Muscarinic cholinergic receptor measurements with $\left[{ }^{18} \mathrm{~F}\right] \mathrm{FP}-\mathrm{TZTP}$ : control and competition studies. J Cereb Blood Flow Metab 18: 1130-1142.

Chen S, Inoue R, Ito Y (1993). Pharmacological characterization of muscarinic receptor-activated cation channels in guinea-pig lieum. Br J Pharmacol 109: 793-801.

Colino A, Halliwell J (1993). Carbachol potentiates Q current and activates calcium-dependent non-specific conductances in rat hippocampus in vitro. Eur J Neurosci 5: 1198-1209.

Cunningham K, Lakoski J (1988). Electrophysiological effects of cocaine and procaine on dorsal raphe serotonin neurons. Eur J Pharmacol 148: 457-462.

De Jong R (1994). Local Anesthetics, 1st edn. Mosby: St Louis.

DeGrado G, Turkinton T, Williams J, Hoffman J, Coleman R (1994). Performance characteristics of a whole body-PET scanner. J Nucl Med 35: 1398-1406.

Dilger J, Brett R, Lesko L (1992). Effects of isoflurane on acetylcholine receptor channels. 1. Single-channel currents. Mol Pharmacol 41: 127-133.

Dilger J, Brett R, Mody H (1993). The effects of isoflurane on acetylcholine receptor channels: 2 . Currents elicited by rapid perfusion of acetylcholine. Mol Pharmacol 44: 1056-1063.

Drevets WC (1998). Functional neuroimaging studies of depression: the anatomy of melancholia. Ann Rev Med 49: 341-361.

Dougherty D, Rauch SL (1997). Neuroimaging and neurobiological models of depression. Harvard Rev Psychiatry 5: 138-159.

Durieux ME (1995). Inhibition by ketamine of muscarinic acetylcholine receptor function. Anesth Analg 81: 57-62.

Durieux ME (1996). Muscarinic signaling in the central nervous system. Recent developments and anesthetic implications. Anesthesiology 84: 173-189.

Fishlock D, Parks A (1966). The effect of 5-hydroxytryptamine on the human ileum and colon in vitro. Br J Pharmacol 28: 164-171.

Flynn DD, Mash DC (1993). Distinct kinetic binding properties of $\mathrm{N}-\left[{ }^{3} \mathrm{H}\right]$-methylscopolamine afford differential labeling and localization of M1, M2, and M3 muscarinic receptor subtypes in primate brain. Synapse 14: 283-293.

Flynn DD, Vaishnav AA, Mash DC (1992). Interactions of cocaine with primary and secondary recognition sites on muscarinic receptors. Mol Pharm 41: 736-742.

Foldes F, Davidson G, Duncalf D, Kuwabara S (1965). The intravenous toxicity of local anesthetic agents in man. Clin Pharm Ther 6: 328-335.

Foldes F, Molloy R, McNall P, Koukal L (1960). Comparison of toxicity of intravenously given local anesthetic agents in man. JAMA 172: 1493-1498.

Ford RD, Balster RL (1976). Reinforcing properties of intravenous procaine in rhesus monkeys. Pharm Biochem Behav 6: 289-296.

Frey KA, Koeppe RA, Mulholland GK, Jewett D, Hichwa R, Ehrenkaufer RLE et al (1992). In vivo muscarinic cholinergic receptor imaging in human brain with $\left[{ }^{11} \mathrm{C}\right] \mathrm{Scopolamine}$ and positron emission tomography. J Cereb Blood Flow Metab 12: 147-154.

Fritze J (1993). The adrenergic-cholinergic imbalance hypothesis of depression: a review and a perspective. Rev Neurosci 4: 63-93.
George DT, Nutt DJ, Linnoila MI (1990). Effect of iv procaine on alcholics with panic. In: Program and Abstracts of the 143th Annual Meeting of the American Psychiatric Association, New York, NY. Abstract NR294.

George DT, Phillips M, Linnoila MI (1993). Effects of procaine on subjects with and without panic disorder. Clin Pharmacol Ther 53: 179.

Gillin JC, Sutton L, Ruiz C, Kelsoe J, Dupont RM, Darko D et al (1991). The cholinergic rapid eye movement induction test with arecoline in depression. Arch Gen Psychiatry 48: 264-270.

Gloor P, Olivier A, Quesney LF, Andermann F, Horowitz S (1982). The role of the limbic system in experiential phenomena of temporal lobe epilepsy. Ann Neurol 12: 129-144.

Haasio J, Hekall R, Rosenberg P (1988). Influence of premedication on lignocaine-induced acute toxicity and plasma concentrations of lignocaine. Br J Anaesth 61: 131-134.

Halgren ED, Walter R, Cherlow DG, Crandall PH (1978). Mental phenomena evoked by electrical stimulation of the human hippocampal formation and amygdala. Brain 101: 83-117.

Hammerbeck DM, Mitchell CL (1978). The reinforcing properties of procaine and $d$-amphetamine compared in rhesus monkeys. J Pharmacology 204: 558-569.

Hartvig P, Tortstenson R, Bjurling $\mathrm{P}$, Fasth KJ, Långström B, Nordberg A (1997). Regional brain distribution and binding of the muscarinic receptor agonist CI-979 studied by positron emission tomography in the monkey. Dement Geriatr Cogn Disord 8: 259-266.

Hasselmo M, Bower J (1992). Cholinergic suppression specific to intrinsic not afferent fiber synapses in rat piriform (olfactory) cortex. J Neurophysiol 67: 1222-1229.

Hasuo H, Gallagher J, Shnick-Gallagher P (1988). Disinhibition in rat septum mediated by M1 muscarinic receptors. Brain Res 438: 323-327.

Heimer L (2003). A new anatomical framework for neuropsychiatric disorders and drug abuse. Am J Psychiatry 160: 1726-1739.

Heynen T, Weiss S, Post R (1995). Local anesthetics effects of kindling modulated by cholinergic agents. NIH Research Festival, Bethesda, MD.

Hisayama T, Takayanagi T, Kumagai N, Kubo H (1989). Interaction of 8 -( $N, N$-diethylamino)octyl 3,4,5-trimethoxybenzoate hydrochloride, ryanodine and procaine with muscarinic cholinergic M2 receptor sites in smooth muscle. J Pharmacol Exp Ther 249: 646-651.

Honer WG, Prohovnik I, Smith G, Lucas LR (1988). Scopolamine reduces frontal cortex perfusion. J Cereb Blood Flow Metab 8: 635-641.

Hsu K, Huang C, Gean P (1995). Muscarinic depression of excitatory synaptic transmission mediated by presynaptic M3 receptors in the rat neostriatum. Neurosci Lett 197: 141-144.

Inoue $\mathrm{M}$, Oomura $\mathrm{Y}$, Nishino $\mathrm{H}$, Aou S, Sikdar SK, Hynes $\mathrm{M}$ et al (1983). Cholinergic role in monkey dorsolateral prefrontal cortex during bar-press feeding behavior. Brain Res 278: 185-194.

Ishii T, Shimo Y (1984). Inhibitory effects of procaine on the contractile responses of the guinea-pig taenia caecum to acetylcholine, substance $\mathrm{P}$ and potassium chloride. Naunyn Schmiedebergs Arch Pharmacol 326: 175-180.

Itoh T, Kuriyama H, Suzuki H (1981). Excitation-contraction coupling in smooth muscle cells of the guinea-pig mesenteric artery. J Physiol 321: 513-535.

Jagoda EM, Kiesewetter DO, Shimoji K, Yamada M, Gomeza J, Wess J et al (2003). Regional brain uptake of the muscarinic ligand [18F]FP-TZTP, is greatly decreased in M2 receptor knockout mice but not in M1, M3 and M4 receptor knockout mice. Neuropharmacology 44: 653-661.

Janowsky D, El-Yousef M, Davis J, Hubbard B, Sekerke H (1972a). Cholinergic reversal of manic symptoms. Lancet 1: 1236-1237. 
Janowsky D, Risch S, Kennedy B, Ziegler M, Huey L (1986). Central muscarinic effects of physostigmine on mood, cardiovascular function, pituitary and adrenal neuroendocrine release. Psychopharmacology 89: 150-154.

Janowsky DS, El-Yousef MK, Davis JM, Sekerke HJ (1972b). A cholinergic-adrenergic hypothesis of mania and depression. Lancet 2: 632-635.

Kellner C, Post R, Putnam F, Cowdry R, Gardner D, Kling MA et al (1987). Intravenous procaine as a probe of limbic system activity in psychiatric patients and normal controls. Biological Psychiatry 22: 1107-1126.

Ketter TA, Andreason PA, George MS, Lee C, Gill DS, Parekh PI et al (1996). Anterior paralimbic mediation of procaine-induced emotional and psychosensory experiences. Arch Gen Psychiatry 53: 59-69.

Ketter TA, Andreason PA, George MS, Pazzaglia PJ, Marangell LB, Post RM (1993). Blunted CBF response to procaine in mood disorders. In: Program and Abstracts of the 146th Annual Meeting of the American Psychiatric Association, San Franciso, CA. Abstract NR297.

Ketter TA, George MS, Kimbrell TA, Benson BE, Post RP (1997). Functional brain imaging in mood and anxiety disorders. Curr Rev Mood Anxiety Disord 1: 95-112.

Kiesewetter D, Carson R, Jagoda E, Herscovitch P, Eckelman W (1999). In vivo muscarinic binding of 3-(alkylthio)-3-thiadiazolyl tetrahydropyridines. Synapse 31: 29-40.

Kiesewetter DO, Lee J, Lang L, Park SG, Paik CH, Eckelman WC (1995). Preparation of 18 F-labeled muscarinic agonist with M2 selectivity. J Med Chem 38: 5-8.

Kling M, Gardner D, Calogero A, Coppola R, Trettau J, Kellner CH et al (1994). Effects of local anesthetics on experiential, physiologic and endocrine measures in healthy humans and on rat hypothalamic corticotropin-releasing hormone release in vitro: Clinical and psychobiologic implications. J Pharm Exp Therapeut 268: 1548-1564.

Klink R, Alonso A (1997). Ionic mechanisms of muscarinic depolarization in entorhinal cortex layer II neurons. J Neurophysiol 77: 1829-1843.

Lenard L, Oomura Y, Nakano Y, Aou S, Nishino H (1989). Influence of acetylcholine on neuronal activity of monkey amygdala during bar press feeding behavior. Brain Res 500: 359-368.

McCormick D, Prince D (1986). Mechanisms of acetylcholine in the guinea-pig cerebral cortex in vitro. J Physiol 375: 169-194.

McCormick D, Prince D (1987). Actions of acetylcholine in the guinea-pig and cat medial and lateral geniculate nuclei, in vitro. J Physiol 392: 147-165.

McPherson RW, Kirsch JRTJR, Ghaly RF, Traystman RJ (1994). Cerebral blood flow in primates is increased by isoflurane over time and is decreased by nitric oxide synthase inhibition. Anesthesiology 80: 1320-1327.

Mesulam M-M (1995). Structure and function of cholinergic pathways in the cerebral cortex, limbic system. In Bloom F, Kupfer D (eds). Psychopharmacology: The Fourth Generation of Progress, Vol 4. Raven Press: New York.

Mesulam M-M, Mufson EJ, Levey AI, Wainer BH (1983). Cholinergic innervation of cortex by the basal forebrain: cytochemistry and cortical connections of the septal area, diagonal band nuclei, nucleus basalis (substantia inominata), and hypothalamus in the rhesus monkey. J Comp Neurol 214: 170-197.

Munson E, Gutnick M, Wagman I (1970). Local anesthetic druginduced seizures in rhesus monkeys. Anesth Analg 49: 986-997.

Napier T (1992). Contribution of the amygdala and nucleus accumbens to ventral pallidal responses to dopamine agonists. Synapse 10: 110-119.

Nurnberger Jr J, Berrentini W, Mendelson W, Sack D, Gershon ES (1989). Measuring cholinergic sensitivity: I. Arecoline effects in bipolar patients. Biol Psychiatry 25: 610-617.
Parekh PI, Spencer JW, George MS, Gill DS, Keller TA, Andreason $\mathrm{P}$ et al (1995). Procaine-induced increases in limbic rCBF correlate positively with increases in occipital and temporal EEG fast activity. Brain Topogr 7: 209-216.

Paxinos G, Huang X-F, Toga AW (2000). The Rhesus Monkey Brain in Stereotaxic Coordinates. Academic Press: San Diego. 408pp.

Penfield WP, Jasper H (1954). Epilepsy and the Functional Anatomy of the Human Brain. Little, Brown: Boston.

Perlis M, Smith M, Orff H, Andrews P, Gillin J, Giles D (2002). The effects of an orally administered cholinergic agonist on REM sleep in major depression. Biol Psychiatry 51: 457-462.

Post R (1981). Lidocaine-kindled limbic seizures: behavioral implications. In Wada J (ed). Kindling 2, Vol 2. Raven Press: New York. pp 149-160.

Post R, Kennedy C, Shinohara M, Squillace K, Miyaoka M, Suda S et al (1984). Metabolic and behavioral consequences of lidocaine-kindled seizures. Brain Res 324: 295-303.

Prohovnik I, Arnold SE, Smith G, Lucas LR (1997). Physostigmine reversal of scopolamine-induced hypofrontality. J Cereb Blood Flow Metab 17: 220-228.

Racine R, Burnham W, Livingston K (1979). The effect of procaine hydrochloride and diazepam, separately or in combination, on cortico-generalized kindled seizures. Electroencephalogr Clin Neurophysiol 52: 204-212.

Racine R, Livingston K, Joaquin A (1975). Effects of procaine hydrochloride, diazepam, and diphenylhydantoin on seizure development in cortical and subcortical structures in rats. Electroencephalogr Clin Neurophysiol 38: 355-365.

Rigdon GC, Pirch JH (1984). Microinjection of procaine or GABA into the nucleus basalis magnocellularis affects cue-elicited unit responses in the rat frontal cortex. Exp Neurol 85: 283-296.

Ritz M, Lamb R, Goldberg S, Kuhar M (1987). Cocaine receptors on dopamine transporters are related to self-administration of cocaine. Science 237: 1219-1223.

Russchen FT, Amaral DG, Price JL (1985). The afferent connections of the substantia innominata in the monkey, Macaca fascicularis. J Comp Neurol 242: 1-27.

Saraswati M, Hashmi M, Abood LG (1992). 4-Bromoacetoamidoprocaine: an affinity ligand for brain muscarinic and nicotinic cholinergic receptors. Neurochem Res 17: 247-252.

Sato T, Kitayama S, Mitsuhata C, Ikeda T, Morita K, Dohi T (2000). Selective inhibition of monamine neurotransmitters by synthetic local anesthetics. Nauyn-Schmiedeberg's Arch Pharmacol 361: 214-220.

Sauerberg P, Olesen P, Nielsen S, Treppendahl S, Sheardown MJ, Honore $\mathrm{T}$ et al (1992). Novel functional M1 selective muscarinic agonists. Synthesis and structure-activity relationships of 3-(1,2,5-thidiazoyl)-1,2,5,6-tetrahydro-1-methylpyridines. J Med Chem 35: 2274-2283.

Scholz A (2002). Mechanisms of (local) anesthetics on voltagegated sodium and other ion channels. Br J Anaesth 89: 52-61.

Scott D (1975). Evaluation of the toxicity of local anesthetic agents in man. Br J Anaesth 47: 56-61.

Servan-Schreiber D, Perlstein WM, Cohen JD, Mintun MJ (1998). Selective pharmacological activation of limbic structures in human volunteers: a positron emission tomography study. Neuropsychiatry Clin Neurosci 10: 148-159.

Sharkey J, Ritz MC, Schenden JA, Hanson RC, Kuhar MJ (1988). Cocaine binding at sigma receptors. Eur J Pharmacol 149: 171-174.

Sitaram N, Nurnberger Jr JI, Gershon ES, Gillin JC (1980). Faster cholinergic REM sleep induction in euthymic patients with primary affective illness. Science 208: 200-202.

Sugimoto M, Uchida I, Fukqami S, Takenoshita M, Mashimo T, Yoshiya I (2000). The alpha and gamma subunit-dependent effects of local anesthetics on recombinant $\mathrm{GABA}_{\mathrm{A}}$ receptors. Eur J Pharmacology 401: 329-337.

Sugita S, Uchimura N, Jinag Z, Norht R (1991). Distinct muscarinic receptors inhibit release of g-aminobutyric acid and excitatory 
aminoacids in mammalian brain. Proc Natl Acad Sci USA 88: 2608-2611.

Szerb J, Clow K, Rasmusson D (1994). Pharmacological but not physiological modulation of cortical acetylcholine release by cholinergic mechanisms in the nucleus basalis magnocellularis. Can J Physiol Pharmacol 72: 839-898.

Wagman I, Jong R, Prince D (1967). Effects of lidocaine on the central nervous system. Anesthesiology 28: 155-172.

Washburn M, Moises H (1992). Muscarinic responses of rat basolateral amygdaloid neurons recorded in vitro. J Physiol 449: 121-154.

Wasterlain C, Masouka D, Jonec V (1981). Chemical Kindling: a study of synaptic pharmacology. In: Wada J (ed). Kindling 2. Raven Press: New York. pp 315-329.
Woods RP, Grafton ST, Holmes CJ, Cherry SR, Mazziotta JC (1998). Automated image registration: I. General methods and intrasubject, intramodality validation. Comput Assist Tomogr 22: 139-152.

Yajeya J, De La Fuente Juan A, Merchan M, Riolobos A, Heredia M, Criado J (1997). Cholinergic responses of morphologically and electrophysiologically characterized neurons of the basolateral complex in rat amygdala slices. Neuroscience 78: 731-743.

Zubieta J-K, Koeppe RA, Frey KA, Kilbourn MR, Mangner TJ, Foster NL et al (2001). Assessment of muscarinic receptor concentrations in aging and Alzheimer disease with $\left[{ }^{11} \mathrm{C}\right] \mathrm{NMPB}$ and PET. Synapse 39: 275-287. 